\title{
Effects of $\pm 3,4-$ Methylenedioxymethamphetamine (MDMA) Administration on Social Emotional Processing in Humans
}

\author{
G. Bedi ${ }^{*}{ }^{1,2}$ and H. de Wit ${ }^{1}$ \\ ${ }^{I}$ Department of Psychiatry and Behavioral Neuroscience, University of Chicago, Chicago, USA \\ ${ }^{2}$ Division on Substance Abuse, New York State Psychiatric Institute \& Department of Psychiatry, College of Physicians \\ and Surgeons of Columbia University, New York, USA
}

Keywords: MDMA, ecstasy, mood, gender, sex.

\section{INTRODUCTION}

Ecstasy users report that the drug produces feelings of increased empathy and sociability [1]. Such 'empathogenic' effects are thought to motivate recreational use of ecstasy [2]. In addition, the rationale for the proposed use of MDMA as an adjunct to psychotherapy centers on these effects [3]. Controlled studies confirm that MDMA administration produces prosocial feelings in humans [e.g. 4], and the drug alters rodent behavior in a way that is consistent with increased sociability [5]. However, there is as yet no evidence that controlled MDMA administration increases behaviors relevant to sociability and empathy in humans. In the present study, we examined the effects of MDMA $(0.75 \mathrm{mg} / \mathrm{kg} ; 1.5 \mathrm{mg} / \mathrm{kg})$ on the identification of others' emotional expressions, and on feelings associated with the 'empathogenic' profile. We also employed an active control drug, the psychostimulant methamphetamine $(20 \mathrm{mg})$, to assess whether these social effects are specific to MDMA, or generalize to other stimulants.

\section{METHODS}

We recruited male and female healthy volunteers $(N=$ 21) who had used ecstasy on at least two occasions. All candidates underwent comprehensive medical and psychiatric screening. The design was within-subjects and double-blind. Across four laboratory sessions, participants received MDMA $(0.75 \mathrm{mg} / \mathrm{kg} ; 1.5 \mathrm{mg} / \mathrm{kg})$, methamphetamine $(20 \mathrm{mg})$ and placebo, in randomized order. During peak drug effects, participants undertook 1) a Facial Emotion Recognition task, in which they identified others' emotional states based on pictures of facial affect [6];2) the Reading the Mind in the Eyes task, which requires participants to identify complex emotions based on pictures of the eye region [7]; and 3) the Diagnostic Analysis of Nonverbal Accuracy [DANVA-2, 8] Adult Paralanguage test, which requires identification of emotions based on vocal cues. Cardiovascular and subjective state measures were obtained repeatedly throughout sessions. The main subjective

*Address correspondence to this author at the Department of Psychiatry and Behavioral Neuroscience, University of Chicago, Chicago, USA; Tel: + 1 212543 5875; Fax: + 122543 6018; E-mail: gb2326@columbia.edu measures were Visual Analog Scale [VAS, 9] 'sociable', 'playful', 'loving' and 'lonely' ratings, and the Profile of Mood States [POMS, 10] 'Friendliness' subscale.

\section{RESULTS}

Participants were 24.4 (S.D. $=4.9$ ) years old, and 12 were male. Previous ecstasy use was light to moderate; they had used the drug on average 15.0 times (S.D. $=23.1$ ). Compared to placebo, MDMA $(1.5 \mathrm{mg} / \mathrm{kg})$ decreased accurate identification of fear from facial cues. MDMA $(1.5 \mathrm{mg} / \mathrm{kg})$ significantly increased ratings of feeling 'loving' relative to placebo, and 'friendly' compared to both placebo and MDMA $(0.75 \mathrm{mg} / \mathrm{kg})$. MDMA $(0.75 \mathrm{mg} / \mathrm{kg})$ increased 'loneliness' relative to placebo and methamphetamine (20mg). Both MDMA (1.5mg/kg) and methamphetamine (20mg) increased 'playfulness' compared to placebo; MDMA $(1.5 \mathrm{mg} / \mathrm{kg})$ also increased 'playfulness' ratings relative to MDMA $(0.75 \mathrm{mg} / \mathrm{kg})$. Methamphetamine $(20 \mathrm{mg})$ significantly increased ratings of 'sociability' compared to placebo.

\section{DISCUSSION}

MDMA produced the expected 'empathogenic' mood profile. However, it did not improve identification of others' emotions, as might be expected in states of increased empathy. Instead, it reduced identification of fear, a threatrelated facial emotional signal, perhaps suggesting that MDMA increases social approach behavior by reducing the extent to which others' negative emotional states are recognized.

\section{CONCLUSIONS}

These findings have implications in terms of both recreational ecstasy use and ongoing trials of MDMA in psychotherapy. Many individuals report using ecstasy for heightened interpersonal connection [2]; such expectations may be altered by the knowledge that MDMA may subtly decrease interpersonal competence. When used therapeutically, alterations in social emotional processing such as reduced fear recognition may contribute to possible benefits of this drug. Should MDMA prove to be effective in psychotherapy, information on the socioemotional and cognitive mechanisms underlying this efficacy will help 
clinical researchers to design treatments that optimize the drug's potential therapeutic effects.

\section{FUNDING}

NIDA DA026570, NIDA DA02812.

\section{DECLARATION OF CONFLICTS}

The authors have no conflicts to declare.

\section{REFERENCES}

Parrott A. The psychotherapeutic potential of MDMA (3,4methylenedioxymethamphetamine): an evidence-based review. Psychopharmacology 2007; 191: 181-93.

[2] Sumnall HR, Cole JC, Jerome L. The varieties of ecstasy experience: an exploration of the subjective experiences of ecstasy. J Psychopharmacol 2006; 20: 670-82.

[3] Holland J. Ecstasy: The complete guide: a comprehensive look at the risks and benefits of MDMA. Rochester, VT, US: Park Street Press 2001.
[4]

Kolbrich EA, Goodwin RS, Gorelick DA, Hayes RJ, Stein EA, Huestis MA. Physiological and subjective responses to controlled oral 3,4-methylenedioxymethamphetamine administration. J Clin Psychopharmacol 2008; 28: 432-40.

[5] Thompson MR, Callaghan PD, Hunt GE, Cornish JL, McGreor IS A role for oxytocin and 5-HT(1A) receptors in the prosocial effects of 3,4 methylenedioxymethamphetamine ("ecstasy"). Neuroscience 2007; 146: 509-14.

[6] Harmer CJ, Shelley NC, Cowen PJ, Goodwin GM. Increased positive $v s$ negative affective perception and memory in healthy volunteers following selective serotonin and norepinephrine reuptake inhibition. Am J Psychiatry 2004; 161: 1256-63.

[7] Baron-Cohen S, Wheelwright S, Hill J, Raste Y, Plumb I. The "Reading the Mind in the Eyes" Test Revised version: a study with normal adults, and adults with Asperger Syndrome or highfunctioning Autism. J Child Psychol Psychiatry 2001; 42: 241-51.

[8] Baum KM, Nowicki Jr S. Perception of emotion: measuring decoding accuracy of adult prosodic cues of varying intensity. J Nonverbal Behav 1998; 22: 89-107.

[9] Folstein MF, Luria R. Reliability, validity, and clinical application of the Visual Analogue Mood Scale. Psychol Med 1973; 3: 479-86.

[10] McNair DLM, Droppleman L. Profile of Mood States. San Diego: educational and industrial testing service 1971.

(C) Bedi and de Wit.; Licensee Bentham Open.

This is an open access article licensed under the terms of the Creative Commons Attribution Non-Commercial License (http://creativecommons.org/licenses/ by-nc/3.0/) which permits unrestricted, non-commercial use, distribution and reproduction in any medium, provided the work is properly cited. 